位，側面の 4 方向がルーチンとなっています，体位保持 による被曝線量, 動摇によるボケ, 再現性等で, 苦労い たしております。これらの問題を少しでも容易ならしめ ようと、リーダー氏撮影台に，自転車のサドルをとりつ け，裏側に含鉛ゴムをとりつけました。カせッテに対 し，任意の角度，距離がと机る棁な金具を製作した，乳 幼児の足腰の力が加わらず，体位保持者は，体位がとり やすく，被瀑線量当少なくなった，我及体位保持者の手 を加えないで，立位背腹撮影の固定法に実餓上の難点 が，ある観点からは改良され，良い結果が得られまし た.

\section{9. 心拍連動位相制御撮影の研究}

\section{第 6 報 制御方式の改良の試み}

\section{仙台鉄道病院放射線科}

芳賀 正一

（目的）心血管の動態をX線学的に解析し，より効率 の高いX線写真を作りX線診断乙役立つことを目的とし た.

（方法） 從来までは心動態のX線写真撮影を行なう場 合，ず単純像の心拍位相制御撮影の造影撮影を行なう 前日又は数特開前に行なっていた．しかしながら 1。 心 腔内に造影剤を注入した場合と注入しない場合の動態的 ならがい．2．時間差又心心拍位相，呼吸位相，幾何学 的な玨現性等の問題から単純像と造影像のX線写真を同 位相同時心拍連続X線撮影が必要となった。そこで従来 の 1. アンギオポリグラフ 2. X線発生装置 3. 連続撮 影装置 4. 造影剤自動注入装置の 4 者 1 Unit 連続作動 方式の一部を改良した。改良点とは，注入装置〔シザー ルII 型〕の作動タイマー回路を利用し従来までは任意の 心拍数遅れでの連続作動方式を行なっていたが，今回は 心拍数に無関係に任意時間遅れの作動方式を切変光スイ ッチで簡単に使用出来るようにした．これによって単純 像から造影像まで連続的に任意位制御撮影が出来るよう になった。

（結論） 從来までは単純X線写真と造影X線写真とを 別々の時聞に撮影を行なって来たが，今回のシステム改 良により単純十造影 X線写真を心拍，呼吸，幾何学的な 点など同位相，同時心拍連続 $\mathrm{X}$ 線写真撮影を行なうこと により心腔内や心動態の計測に大いに有用性が高くなっ たと荐觉る。

\section{0. バンバン（動静脈像）自在撮影装置}

東北大附属病院長町分院

バンバンとは？X-RAYスイッチ 2 回曝射時に発 する音を愛称で乎んでいます。
（目的）血管造影（特に脳血管造影）で連続撮影以外 は動脈像と静脈像の各々 2 枚の写真を医師が希望するの が常である. 静胍像の撮影に関しては造影剤注入後通過 時開を目算したりストップロオッチ等で計りながら撮影 するのが一般的であったので，時間も不正確となり又医 師とのタイミングも合致せず，立派な写真が得られませ ん. 当長町分院では結線図に示す通り一回の押しボタン 操作で撮影の完了する装置を考栄作製しましたので報告 致します。

（結論） 静脈像撮影の際は動脈像撮影後何秒後に路出 するかが問題となります，医師より指定される静脈像撮 影の時間設定が 1 秒〜 10 秒なで自在に選択出来て完全自 動は勿論の事確実て然も安易に動静脈像の撮影が出来る 限時装置である。

\section{1. 当センター放射線技師の被曝について}

宮城県立成人病センター

$$
\begin{aligned}
& \text { ○西谷 亨子 早川，博文 } \\
& \text { 荒 らみ子 }
\end{aligned}
$$

当センターが，昭和 42 年 4 月に開院以来， 5 年が過ぎ ました，气の間に，我及放射線業務従事者が，どれ位被 曝したかについて検討してみしまた。 すず最初に，X線 発生装置室の使用頻度を調べ，35\%と一番それの高いX 線テレビ室での散乱線分布状況を調べました。 その時

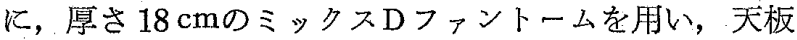
を $180^{\circ}$ に倒した状熊で, 管電圧 $80 \mathrm{kvp}$, 管電流 $1 \mathrm{~mA}$, 線量計は東芝製電離槽型サーベイメーダーを使用しまし た結果，距離 $1 \mathrm{~m} て ゙ ~ 25 \mathrm{mR} / \mathrm{h}$ 位でした。次に，我々の稼 動状況を調べ，最後に，個人被暴蓄積線量を調べまし た．それの測定には，X線用フイルムバッチをと線用フ イルムバッチを使用し，その結果Aは133，Bは130，C は130と全員， $150 \mathrm{mR} /$ Year来満でした．昭和45年の石 坂氏等が報告したものと比䡥しても当せンターでの被曝 管理は，ある程度十分であるという結諭に達しました。

\section{2. 特殊造影透視時における術者の被曝線量}

\section{青森県立中央病院}

检庭 昇一平井 康子 相沢，正明

最近 TV 遠隔操作等により術者の被曝線量は軽隇して おりますが，心血管造影等においては患者のそぼにあっ て術者が，主射，その他の操作をする場合には被曝を受 けます：その線量が身体各部にどれ位被曝するか測定 し，又，参考のため同様の装置を使用している各室につ いても測定し屯した。

測定方法はテーブルサイドとテーブルより $50 \mathrm{~cm}$ 離れ た時，床面より $60 \mathrm{~cm}$ から $160 \mathrm{~cm}$ までの高さについて， 